\title{
イネ葉の老化プログラムに関する三次元的解析
}

\author{
稲田のりこ \\ 東京大学大学院理学系研究科生物科学専攻 \\ （T113-0033 東京都文京区本郷7-3-1）
}

\section{Three-dimensional analyses of the senescence program in rice leaves}

\author{
Noriko Inada \\ Department of Biological Sciences, Graduate School of Science, University of Tokyo \\ Hongo, Tokyo 113-0033, Japan
}

要旨 : 老化は、発生の最終段階として、植物体の中の遺伝的プログラムの下に厳密な制御を受けて進行す る過程である。我々は老化機構の解明を最終目的とし、先ず老化の開始から進行の過程を組織・細胞レベル で明らかにして来た。生活環が短く、構造が単純なイネの子葉鞘を主に材料として用い、その一連の解析の 結果、自然老化と通気組織形成という二つの異なるタイプの細胞死の進行過程が詳細に明らかになった。組 織レベルでは両者の進行パターンは大きく異なるが、細胞レベルでは、オルガネラDNAの分解や液胞崩壊 などの極初期・また最終段階の主要な過程が、両者て同様に観察された。これらの結果は、全ての練胞で同 一の死のプログラムが働いており、その進行が周囲の環境から大きく影響を受けていることを示唆してい る。

Summary: Senescence of the higher plant is genetically programmed as the last stage of the development. As the first step to clarify the whole mechanism of senescence, we characterized the pattern of senescence at both the tissue and cellular levels. The coleoptile of rice, which has a short life span and a simple structure, has been used mainly as the material for this study. A series of morphological analyses revealed two different types of programmed cell death in the coleoptile; natural senescence and aerenchyma formation. Although the progression at the tissue level differed largely between two types of death, initial and last events at cellular level were highly conserved in both processes. These facts suggest that the program of cell death would be identical in all cells of the coleoptile and the progression of the program would be affected largely by the surroundings.

Key words: aerenchyma, coleoptile, Oryza sativa, programmed cell death, senescence 


\section{I. はじめに}

高等植物の老化は、発芽・成熟に次ぐ発生の最終段階として遺伝的に制御された積極的分解の過程であ る、との認識のもとに古くから研究が行われてきた（Leopold, 1961）。葉に於けるクロロフィルの分解や 光合成活性の低下、タンパク質分解またそれら分解醳素活性の上昇など、老化時に起こる分解・退化の過 程、あるいは老化を誘発するものとしての植物ホルモンや光・養分など外的要因との関連は、形態・生化・ 生理学、様々な視点から記述されている（Noodén and Leopold 1988）。現在これまでに単離されている 老化関連遺伝子の解析とともに、その網羅的探索が進められつつあり（Buchanan-Wollaston 1994;

Quirino et al. 2000）、老化研究は全体としては膨大な量に及ぶ。しかし、それら個々の情報は未だ断片的 な知識に留まっており、一連の流れとして老化の機構を捉えることの出来る段階には程遠い。

我々は、老化の機構の解明に際して、先ず老化に際して起こる諸現象を、ひとつの流れとして組織・細 胞・オルガネラレベルで詳紏に解析し、その上で各現象の機構について解析を進めることが必要である、と の考えから、これまでに研究を進めてきた。

\section{II. 子葉輎の緑化領域における老化の進行}

本研究では、老化のモデル系として、イネの子葉鞘を主に用いている。子葉鞘は、播種してから成熟しそ の後枯死に至るまでの期間が、1週間と非常に短い（図1）。更に、維管束が2本しか無い単純な組織構造、 葉緑体DNAが1つから3つにまとまっていてその挙動解析が容易、など、組織・細胞・オルガネラレベルで 老化の進行を解析するのに、非常に適した特徵を持つ。

先ず、子葉鞘内のクロロフィル局在を三次元的に観察し、組織レベルでの老化進行を調ベた。その結果、 老化は先端から基部、葉の内側から表皮、葉の両側・及び中央部から維管束の方向に進むことが明らかにな り、また維管束周辺の細胞で著しく老化が遅れることが示された。

この結果に基づき、子葉鞘横断切片から、それぞれ老化時期の異なる3 領域を選んで、テクノビット切片 染色法により細胞内構造の変化を観察した（図2）。その結果、全ての緑化する葉肉細胞で、(i)葉緑体DNA の減少、(ii)ルビスコの分解、葉緑体サイズの減少、細胞核の凝縮、(iii)葉緑体膜の分解、(iv)細胞内構造の 崩壊、という同一の過程を経て老化が進行してゆくことがわかった。これら各現象の起こる時期・速度は、 子葉鞘内の場所により違いが見られた。以上の結果は、全ての緑化する葉肉細胞に同一の老化プログラムが 存在しており、その進行が環境による影響を強く受けていることを示唆している (Inada et al. 1998a,b) 。

\section{III. 子葉鞘の非緑化領域における老化の進行}

子葉鞘の葉肉細胞は背軸側2-3層（外層）の緑化細胞と、向軸側3-7層（内層）の非緑化細胞とに分けら れる。内層では、播種後2日目にアミロプラストが分化し、その後一日で完全にデンプンが分解される、と いう激しい変化が見られる。テクノビット切片染色法による解析の結果、内層では外層よりも早く老化が進
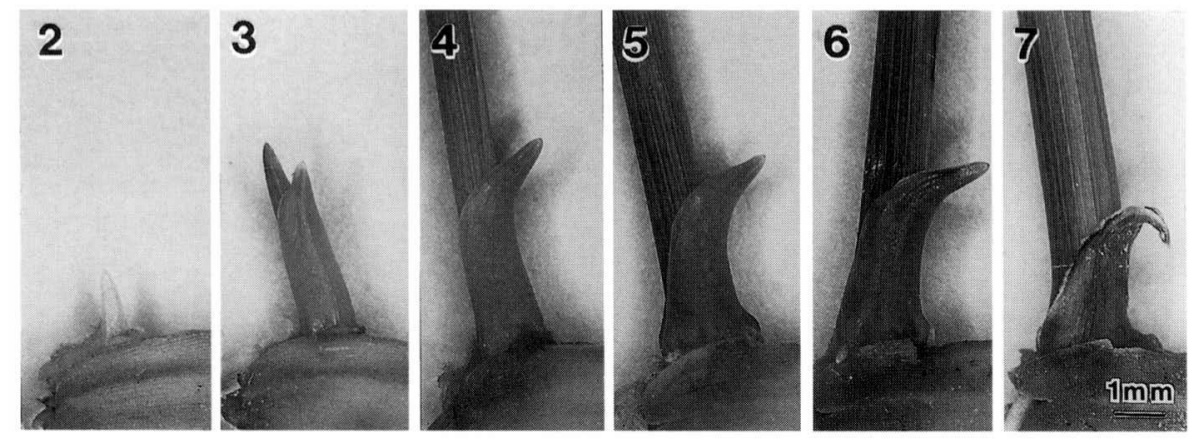

図1.イネの種子を一晚吸水さ せ、30度の連続光照射下で有て ると、播種後 2 日目に子葉踃が 現れ、3日目にはほほ完全に成 長を終え、その後老化して7日 目には完全に枯死する。数字は 播種後の日数を表す。 

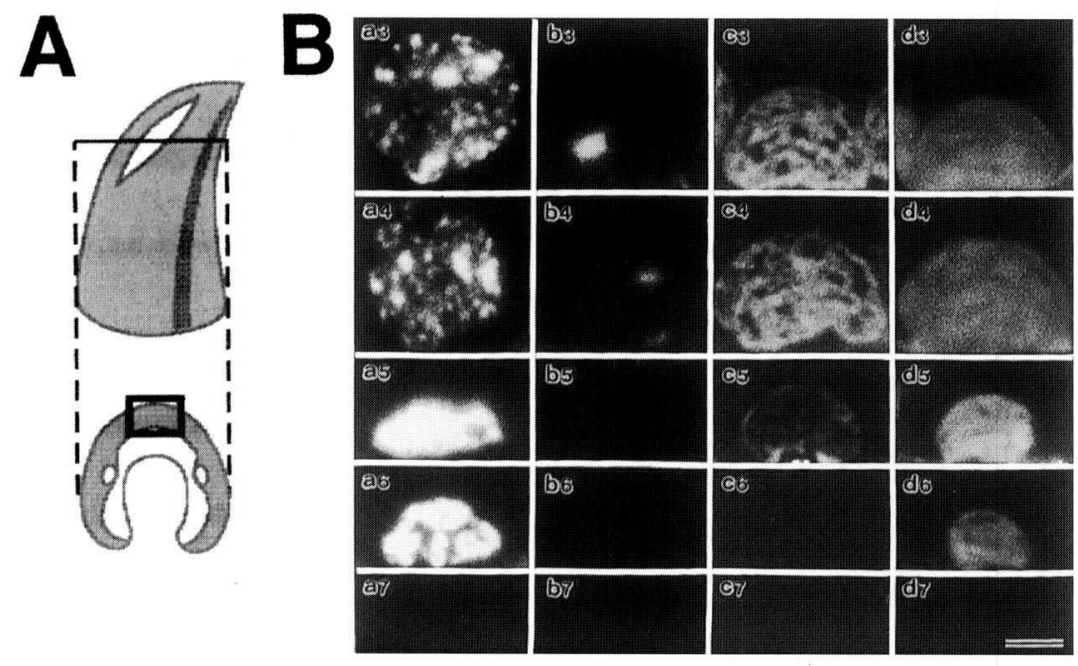

図2. 子葉鞘横断切片維管束間領域 の緑化葉肉細胞 (A) に於计る細

胞核 (a)・フラスチドDNA

(b) ・ルビスコ (c) ・フラスチ ド膜 (d) の経時的変化 (B)。广 クノビット切片をDAPIとFITCでそ れぞれ可視化されているルビスコ 抗体、DAPIとDiOC,で二重染色 し、蛍光顕微鏡下で観察した。ア ルファベットの後の数字は播種後 の日数を表す。バ一は2 $\mu \mathrm{m}$ 。

行し、細胞内構造の消失と共に細胞壁が著しく変形することがわかった。

吸水直後の発生初期の段階から老化に至るまでの組織・細胞の変化を、蛍光顕微鏡・及び電子顕微鏡で詳 細に観察した結果、内層における向軸側表皮から3-4層目の細胞で、播種後3-4日目にかけて急激な細胞死 が起こり、この細胞死がその後両表皮側に向かって広がってゆくことが明らかになった。これらの非常に早 く老化が進行する内層内部の細胞は、通気組織の形成に関与する部分である (Kawai and Uchimiya 2000）。細胞内では、発生の早い段階に於けるプラスチドDNAの減少・それに続くミトコンドリアDNAの 減少は、外層の緑化細胞を含む全ての紐胞で平行して進行していた。しかし、通気組織形成部位において は、外層・及び向軸側表皮に隣接した一層の細胞で老化後期に見られたような、練胞核の凝縮は確認されな かった（Inada et al. in press）。

これらプラスチド及び細胞核の変化は、普通葉である第二葉葉身においても子葉鞘と同様の順序で観察さ れた（Inada et al. 1999）。イネの第一葉（Sodmergen et al. 1991）、また、ホウレンソウの葉でも

(Scott and Possingham 1980) 、老化の極初期に葉緑体DNAの分解が起こることが知られている。更に 細胞核の凝縮は、動物細胞におけるプログラム細胞死（PCD）の一種であるアポトーシスに特徵的な現象 として良く知られており（Kerr et al. 1972）、植物でも、老化を含む様々な死の過程において既に多数例 報告されている (Wang et al. 1996; McCabe et al. 1997; O'Brien et al. 1998; Wang et al. 1999)。これ らの結果は、イネの葉で観察された老化プログラムが、細胞死のプログラムとして一般に広く適応され得る ことを示唆している。

\section{IV. 子葉鞘の老化時に活性を示すヌクレースの解析}

以上に述べた老化のプログラムには、各オルガネラDNAの分解にそれぞれ㗢いているヌクレ一スが重要 な役割を果たしていることが予想された。そこで、老化子葉鞘のヌクレースについて解析を進めた。しか し、従来の生化学的手法では、葉の中の場所の違いによる老化時期の違いとヌクレースの挙動を関連づけて 解析を行うことは難しい。そこで、1960年にDaoustとAmanoにより報告された、組織内のヌクレ一ス活 性を可視化して解析するフィルム基質法に着目し、これを子葉鞘の系に応用することにした。以下にフィル ム基質法の概略を説明する。

先ずゼラチンと仔牛胸腺DNAとの混合液を用いてカバーガラス上に薄いフィルムを作り、その上に組織 切片を乗せる。37度で暫く反応させた後、切片を取り除き、フィルムをDNA特異的色素で染色して顕微鏡 下で観察し、色素で染色されない部分をヌクレース活性の高い部分として検出する。DaoustとAmanoによ る最初のプロトコールでは、用いるゼラチンとDNAの濃度が5-7\%と非常に高く、また試料としては凍結切 


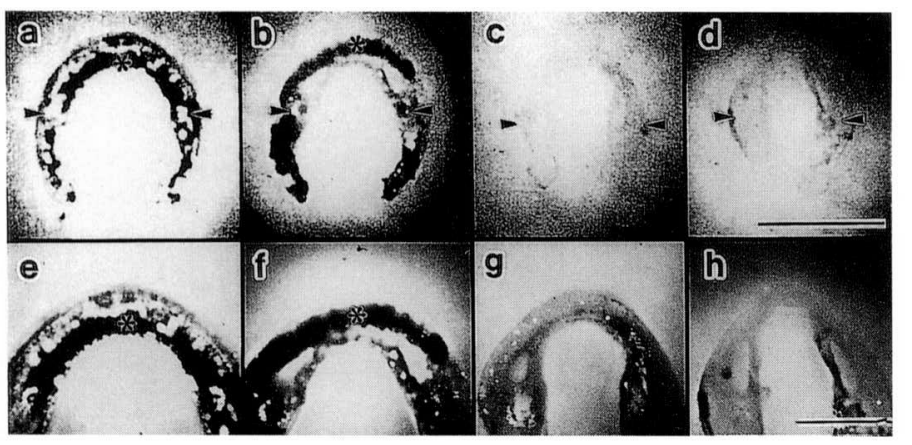

図3. $\mathrm{Ca}^{2+} / \mathrm{Mg}^{2+}$ 依存性ヌクレ一ス活性の子葉鞘に おける局所性の経時的変化。子葉鞘の横断切片を 乗せて反応させた後、DAPI染色したDNAフィル 厶全体像（a-d）、及び維管束間領域の拡大像

(e-h)。DAPIで染色されず黒く抜けているとこ ろ (星印) がヌクレース活性の高い部分を示して いる。矢頭は維管束の位置を表す。バーはそれぞ १20.5 mm (d) $0.1 \mathrm{~mm} \mathrm{(h)。}$

片が用いられていた。フィルムの均一化・感度上昇のために各溶液の濃度を低くする、また簡略化のため生 切片を用いる、などの改変を行い、子葉鞘内の場所によるヌクレース活性の違いを検出することに成功し た。また、切片に様々な金属イオンを含む溶液を与えて反応させることにより、ヌクレースの金属イオンに 対する要求性も調ベた。

図3に、老化に伴う $\mathrm{Ca}^{2+} / \mathrm{Mg}^{2+}$ ヌクレース活性の子葉鞘横断切片内局在の変化を、フィルム基質法により 解析した結果を示す。4日目に、内層の通気組織形成部位で、局所的に強い $\mathrm{Ca}^{2+} / \mathrm{Mg}^{2+}$ 要求性のヌクレース 活性が見られた。更に5日目になると、これら通気組織部位の細胞は最早ヌクレース活性を示さず、外層で ヌクレース活性が検出された。もつと若い時期の子葉鞘・及び更に老化が進んだ子葉鞘ではこのような強い ヌクレース活性は得られず、また、他の金属イオン、及び $\mathrm{Ca}^{2+} \cdot \mathrm{Mg}^{2+}$ それぞれ単独で与えた場合には、明 らかな局所性を示す再現的な結果は得られなかった。更に、このヌクレース活性が切片のEDTA溶液処理に より阻害されたことから、子葉鞘の老化細胞では $\mathrm{Ca}^{2+} / \mathrm{Mg}^{2+}$ 要求性ヌクレースが重要な役割を果たしている ことが更に支持された。

$\mathrm{Ca}^{2+} / \mathrm{Mg}^{2+}$ 要求性ヌクレースが老化及び細胞死に関わる例は、動物ではこれまでにも多数知られており (Peitsch et al. 1993; Shiokawa et al. 1994; Zhivotosky et al. 1994; Yakovlev et al. 2000) 、植物で も、水没させたイネ子葉鞘の系を用い、老化時期に特異的な活性を持つ $23 \mathrm{kDa}$ のヌレースが川合と内宮 により同定されている（2000）。現在我々もDNA入りのポリアクリルアミドゲルを用いたゲル内アッセイ 法を用い、通気組織形成や老化に関与するヌクレース分子の同定を試みている。

\section{V. 通気組織形成における細胞死始源細胞の探索とその伝播様式の解析}

前章のフィルム基質法解析により得られた $\mathrm{Ca}^{2+} / \mathrm{Mg}^{2+}$ 要求性ヌクレースの活性局在パターンは、反応時に 切片に水のみを与えた場合にも同様に観察された。このことから、細胞内にこれらの金属イオンが存在し、 その濃度が老化時に上昇することによってヌクレースの活性化が起こるのではないか、との仮説を立てた。 これを検証するため、 $\mathrm{Ca}^{2+}$ 指示蛍光試薬Calcium Green $1 \mathrm{AM}$ (CG1) を用い、子葉鞘の横断生切片を経時 的に観察した。その結果、播種後4日目の通気組織形成部位にのみ特異的に、CG1シグナルが見られること
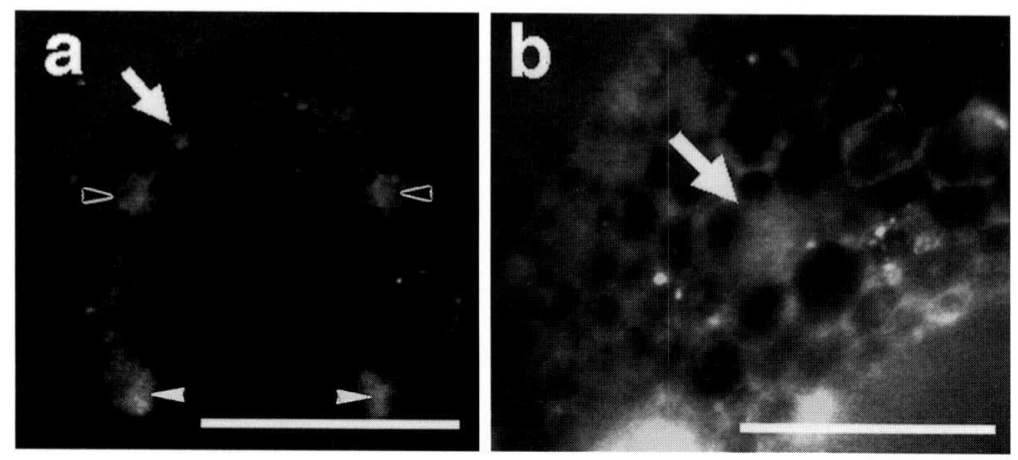

図4.CG1で染色した子葉韧生横断切片 (a)、及び維管束近辺の拡大像 (b)。播 種後3-4日目の子葉鞘は、維管束 (黒矢頭) 及び両端部分 (白矢頭) に、他の時期には 見られないシタナルを常に持つが、それと は別に、通気組織形成部位では維管束から 3細胞目、内表皮から3層目の細胞で最初に シグナルが見られる。バーは0.5 mm

(a) $0.1 \mathrm{~mm}$ (b) 。 


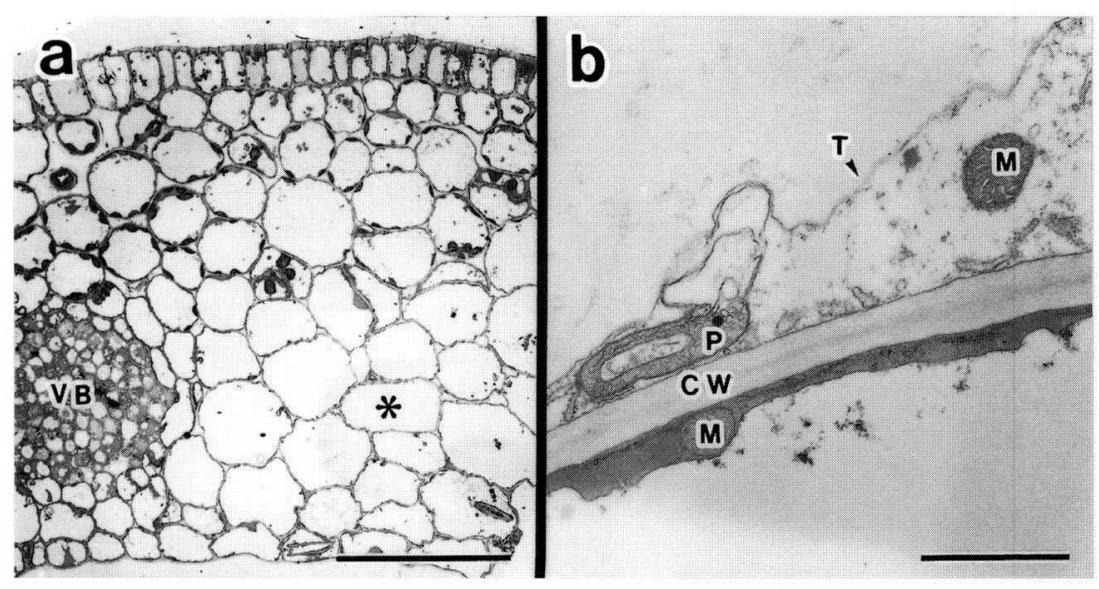

図5. 通気組織形成時における細胞死 始源細胞 (a、*) とその拡大像 (b) の電子顥微鏡写真。維管束 （VB） から3細胞目、内表皮から3層 目の細胞で、液胞膜 (T) の崩壊に伴 い、著しい細胞質の膨潤が引き起こさ れている。CW、細胞壁；P、プラス チド；M、ミトコンドリア。バーはそ れぞれ50 $\mu \mathrm{m}$ (a) 、1 $1 \mu \mathrm{m}$ (b) 。

がわかった。そこで更にCa ${ }^{2+}$ 可視化の手法を用いて、3日目から4日目にかけての通気組織形成の過程を詳細 に解析し、このシグナルがある決まった位置の細胞から始まり一定の順序で子葉鞘内に伝播していくことを 突き止めた。

先端から $1 / 3$ の位置で作成した横断切片内に於いて、このシグナルは、維管束から 3 細胞目、向軸側表皮 から3層目の細胞で最初に観察される（図4）。その後、反対側の維管束近辺でも同様の位置からシグナル が現れ、両側から中央部に向かって一細胞層で広がってゆく。また、維管束間領域から少し遅れて、両端部 でも、維管束近辺の同様の位置から維管束から離れる方向に向かうCG1シグナルの伝播が見られる。現在、 先端一基部の縦軸で、このシグナル伝播がどのように進行するのかを更に詳細に解析しており、子葉鞘中央 部の特定の位置から始まって上下方向に進行してゆく通気組織形成の過程が明らかになりつつある。また、 電子顕微鏡観察から、隣接する細胞が完全に健常な構造を保持している一方、CG1シグナルを示す細胞で は、液胞崩壊による著しい細胞内構造の膨潤が引き起こされ、急激な細胞死が起きていることが明らかに なった（図5）。

通気組織形成に伴う細胞死が、組織レベルである一定の位置から開始し一定の順序で伝播してゆく、その 大まかな道筋は、これまでにもイネの根・葉でそれぞれ観察されている（Kawai et al. 1998; Matsukura et al. 2000)。しかし、根や第二葉などの器官においては、その構造の複雑さや対称性、器官としての大き さなどの問題から、細胞死始源細胞の厳密な位置を決定することは困難である。本研究では、サイズが小さ く構造が単純な子葉鞘を用い、通気組織形成時の細胞死の開始と伝播の様式を三次元的に明確に示すことに 成功した。これらの結果は、細胞死の開始・進行を研究する上で、非常に重要な意義を持つものと期待され る。

\section{VI.おわりに}

以上に述べた解析から、子葉鞘内に於ける2種類の死の過程、即ち自然老化と通気組織形成時の細胞死 が、組織・細胞レベルで明らかになった。組織レベルにおいては両者の進行過程は大きく異なる（図 6A）。自然老化が、縦軸では先端から基部、横軸では葉の両側・及び中央部から維管束の方に向かって進 行するのに対し、通気組織形成は、縦軸では子葉鞘中央部から上下方向、横軸では維管束近辺の一細胞から 始まって維管束から離れる方向に進んでゆく。しかし、細胞内では（図6B）プラスチド・ミトコンドリア DNAの分解・それに続くプラスチドの分解が、両細胞内で平行して同様に観察される。通気組織形成細胞 では細胞核の凝縮が見られないが、最終的に液胞崩壊が起こり細胞内構造の崩壊を引き起こす、という終末 の迎え方は老化細胞と共通している。これらの結果から我々は、全ての細胞内に同一の、死に向かうプログ ラムが存在し、そのプログラムに組み込まれている各現象の発現が、環境の影響を受けて早まったり遅まっ たりする、というモデルを立てている。つまり、通気組織形成では、最終ステップとしての液胞崩壊が、何 


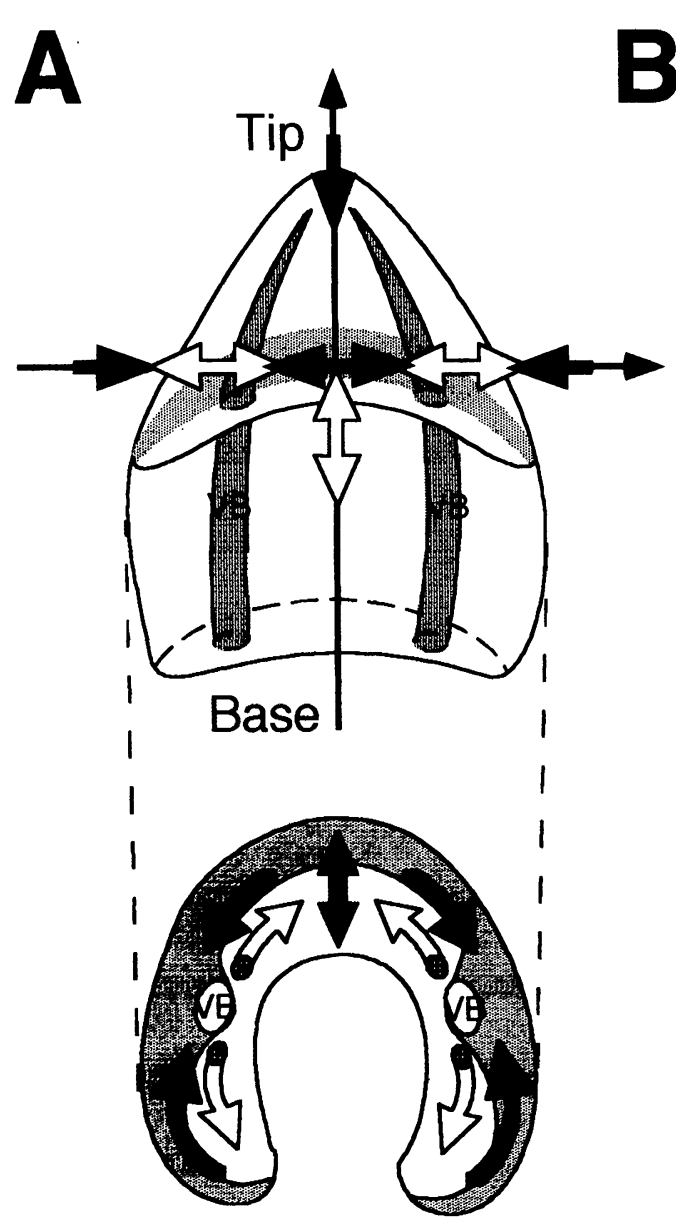

Natural
senescence

$\begin{array}{cc}\text { Aerenchyma } & \text { Days } \\ \text { formation } & \text { after }\end{array}$
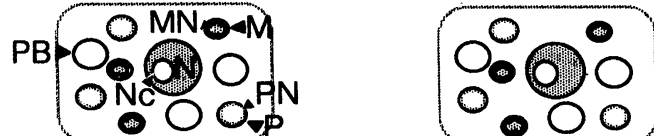

sowing
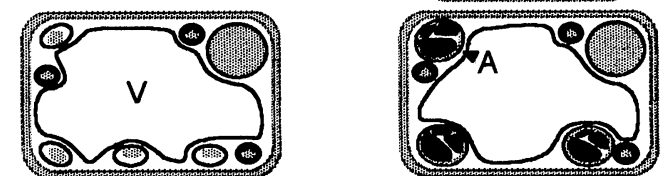

2
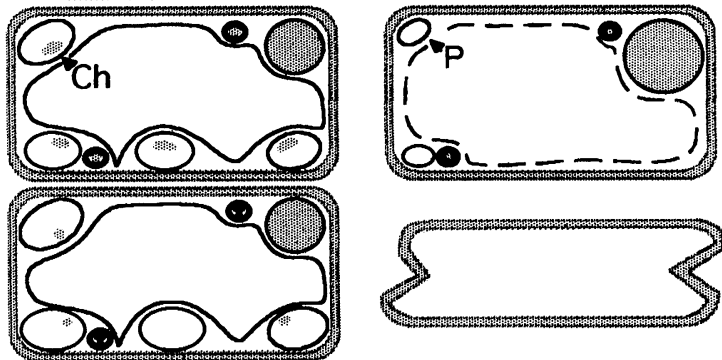

3



4
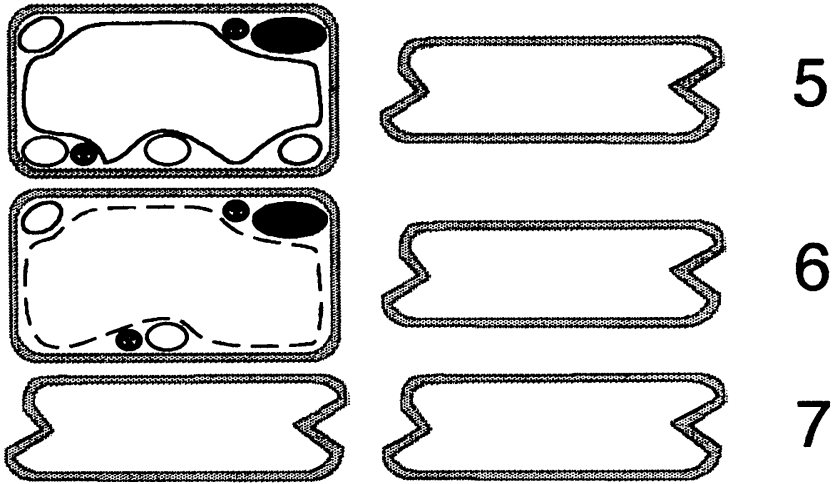

図6. 子葉鞘に於ける自然老化、及び通気組織形成に関わる細胞死の組織 (A) ・細胞 (B) レベルの進行パターン。組 織レベルでは、二つはその進行パターンが大きく異なり、自然老化 (黒矢印) が先端から基部、中央部・及び両端から 維管束 (VB) の方に向かって進行するのに対し、通気組織形成 (白矢印) は、子葉鞘の中央部から上下方向、維管束近 辺の一細饱維管より始まり維管束から離れる方向に進行する。細胞レベルでは、両方とも、極初期に於けるフラスチ ド・ミトコンドリアDNA（PN、MN）の滅少は平行して起こるが、その後通気組織形成では液胞 (V) の崩壊による細 胞内構造の膨泪、分解が急激に進行するのに対し、自然老化では更にプラスチド (P) の分解・細胞核 (N) の凝縮と 言った現象が稓察され、最後に液胞崩壊に伴う細胞内構造の分解が起こる。A、アミロフラスト；Ch、葉緑体；M、ミ トコンドリア；Nc、核小体；PB、プロインボディ。

らかの環境要因により非常に早く、細胞核の凝縮が引き起こされるよりも以前に誘発され、結果として細胞 核の凝縮という過程はスキップされて、そのまま急激な細胞死に至るのである。液胞崩壊が最終決定権を持 つような細胞死の過程は、植物PCDのモデル系として研究が進んでいる維管束形成の際にも起こることが 知られている（Fukuda 1997; Groover et al. 1997; Kuriyama 1999）。維管束形成の際のオルガネラ DNAの変化に関しては記述が無いものの、ここでもイネ葉の例と同様の機構が働いているのではないかと 予想している。

高等植物は全発生段階を通じて様々な種類のPCDを経験するが（Mittler 1998）、それらが同じプログラ ムにより進行しているのか、それともそれぞれ別の機構により制御されているのかは、非常に興味が持たれ ている点である。この疑問に答えるための試みの一つとして、Pontierらは老化や過敏感細胞死の遺伝子マ 一カーを用い、様々な条件下におけるそれら遺伝子のmRNA蓄積の違いを調べるという実験を行った （1999）。解析の結果は、老化と過敏感細胞死の間で何らかのクロストークはあるものの、空間的・及び 
時間的な両細胞死関連遺伝子の発現制御は異なる、という結論を導き出すものであった。しかし、そもそも それらの遺伝子が細胞死のプログラムの中でどのような位置を占めているのかもわかっておらず、このよう な解析から死のプログラム全体を捉えることは現段階では困難であると言える。

イネ葉における我々の結果は、老化を含む全ての細胞死が同じプログラムのもとに制御されている可能性 を強く示唆している。このプログラムには、各オルガネラDNAの分解が主要な過程として関与しているこ とが予想される。今後は、老化の時期・場所特異的に働くヌクレース分子の更なる解析や、また通気組織形 成の際の細胞死とその伝播に関わる物質の解析、及び細胞死始源細胞特異的に発現する遺伝子の探索などに より、更に老化・紏胞死の機構を明らかにしていこうと考えている。

\section{謝辞}

本総説に関する一連の研究は、奈良女子大学助教授酒井敦博士、東京大学助手黒岩晴子博士、東京大学 教授黒岩常祥博士及び東大黒岩研究室の皆様のご指導、ご助言の元に行われたものであり、ここに深く感謝 致します。

\section{引用文献}

Buchanan-Wollaston V (1997) The molecular biology of leaf senescence. J Exp Bot 48: 181-199

Daoust R, Amano H (1960) The localization of ribonuclease activity in tissue sections. J Histochem

Cytochem 8: 131-134

Fukuda H (1997) Tracheary element differentiation. Plant Cell 9: 1147-1156

Groover A, DeWitt N, Heidel A, Jones A (1997) Programmed cell death of plant tracheary elements differentiating in vitro. Protoplasma 196: 197-211

Inada N, Sakai A, Kuroiwa H, Kuroiwa T (1998a) Three-dimensional analysis of the senescence program in rice (Oryza sativa L.) coleoptiles. - Investigations of tissues and cells by fluorescence microscopy. Planta 205: 153-164.

- - - (1998b) Three-dimensional analysis of the senescence program in rice (Oryza sativa L.) coleoptiles. - Investigations by fluorescence microscopy and electron microscopy. Planta 206: 585-597.

- - - (1999) Senescence program in rice (Oryza sativa L.) leaves: analysis of the blade of the second leaf at the tissue and cellular levels. Protoplasma 207: 222-232

- - - Senescence of the non-greening cells in the rice (Oryza sativa L.) coleoptile. Protoplasma in press.

Kawai M, Samarajeewa PK, Barrero RA, Nishiguchi M, Uchimiya H (1998) Cellular dissection of the degradation pattern of cortical cell death during aerenchyma formation of rice roots. Planta 204: 277-287

Kawai M, Uchimiya H (2000) Coleoptile senescence in rice (Oryza sativa L.). Ann Bot 86: 405-414

Kerr JFR, Wyllie AH, Currie AR (1972) Apoptosis: a basic biological phenomenon with wide-ranging implications in tissue kinetics. Br J Cancer 26: 239-257

Kuriyama H (1999) Loss of tonoplast integrity programmed in tracheary element differentiation. Plant Physiol 121: 763-774

Leopold AC (1961) Senescence in plant development. Science 134: 1727-1732

McCabe PF, Levine A, Meijer PJ, Tapon NA, Pennell RI (1997) A programmed cell death pathway activated in carrot cells cultured at low cell density. Plant J 12: 267-280 
Matsukura C, Kawai M, Toyofuku K, Barrero RA, Uchimiya H, Yamaguchi J (2000) Transverse vein differentiation associated with the air space formation-cell fate of middle layer in leaf sheath development of rice. Ann Bot 85: 19-27

Mittler R (1998) Cell death in plants. in When cells die. Edited by Lockshin RA, Zakeri Z and Tilly JL. chapter 5; 147-174 Wiley-liss Inc., NY, U.S.A.

Noodén LD, Leopold AC (1988) Senescence and aging in plants. Academic Press, California

O'Brien IEW, Murray BG, Baguley BC, Morris BAM, Ferguson IB (1998) Major changes in chromatin condensation suggest the presence of an apoptotic pathway in plant cells. Exp Cell Res 241: 4654

Peitsch MC, Polzar B, Stephan H, Crompton T, MacDonald HR, Mannherz HG, Tshcopp JT (1993) Characterization of the endogenous deoxyribonuclease involved in nuclear DNA degradation during apoptosis (programmed cell death). EMBO J 12: 371-377

Pontier D, Gan S, Amashino RM, Roby D, Lam E (1999) Markers for hypersensitive response and senescence show distinct patterns of expression. Plant Mol Biol 39: 1243-1255

Quirino BF, Noh YS, Himelblau E, Amasino RM (2000) Molecular aspects of leaf senescence. Trends Plant Sci 5: 278-282

Scott NS, Possingham JV (1980) Chloroplast DNA in expanding spinach leaves. J Exp Bot 31: 10811092

Shiokawa D, Ohyama H, Yamada T, Takahashi K, Tanuma S (1993) Identification of an endonuclease responsible for apoptosis in rat thymocytes. Eur J Biochem 226: 23-30

Sodmergen, Kawano S, Tano S, Kuroiwa T (1991) Degradation of chloroplast DNA in second leaves of rice (Oryza sativa) before leaf yellowing. Protoplasma 160: 89-98

Wang H, Li J, Bostock RM, Gilchrist DG (1996) Apoptosis: a functional paradigm for programmed plant cell death induced by a host-selective phytotoxin and invoked during development. Plant Cell 8: 375-391

Wang M, Hoestra S, van Bergen S, Lamers GEM, Oppedijk BJ, van der Hijden MW, de Priester W, Schilperoort RA (1999) Apoptosis in developing anthers and the role of ABA in this process during androgenesis in Hoedeum vulgare L. Plant Mol Biol 39: 489-501

Yakovlev AG, Wang G, Stoica BA, Boulares HA, Spoonde AY, Yoshihara K, Smulson ME (2000) A role of the $\mathrm{Ca}^{2+} / \mathrm{Mg}^{2+}$-dependent endonucleases in apoptosis and its inhibition by poly(ADPribose)polymerase. J Biol Chem 275: 21302-21308

Zhivotosky B, Wade D, Nicotera P, Orrenius S (1994) Role of nucleases in apoptosis. Int Arch Allergy Immunol 105: 333-338 